\title{
UPAYA PENINGKATKAN KUALITAS GARAP KOREOGRAFI ANAK MELALUI METODE INDIVIDUAL MAHASISWA JURDIK SENI TARI FBS UNY
}

\section{Marwanto}

Jurusan Pendidikan Seni Tari FBS UNY

\section{Abstract}

Children choreography is creating dances for children that are suitable with their ways of thinking and playing world. This research is aimed at improving quality of children choreography. The expectation is that the choreography might become subject of excellence and brings a good name to the Dance Art Education Department specifically and Yogyakarta State University generally.

This study applied class action research, with students of Composition and Choreography II Classes in the even semester of 2005/ 2006 as its subject.

The result shows that the students' academic achievement and the quality of their choreography increased significantly. Out of 22 students' creations, 4 are taken as models of dance learning in primary, junior high and senior high schools.

Key words: Children choreography, subject of excellence

\section{A. Pendahuluan}

Di dalam kurikulum 2002 program studi pendididkan seni tari, terdapat mata kuliah Komposisi dan Koreografi II sebagai mata kuliah praktik yang di dalam proses belajar mengajarnya (PBM) mahasiswa diwajibkan untuk membuat karya tari. Penyusunan gerak yang diolah dibatasi hanya pada gerak tari yang khusus disusun untuk anak-anak. Hal ini mendukung program unggulan yang telah dicanangkan pada masing-masing program studi di lingkungan Universitas Negeri Yogyakarta yaitu Koreografi anak.

Mata kuliah ini mewajibkan para penari/peraga tari adalah anak-anak atau remaja yang berusia Sekolah Dasar (SD) sampai dengan Sekolah Menengah Atas (SMA). Jadi para mahasiswa tersebut membuat karya tari, kemudian diajarkan kepada para penari yang terdiri dari anak-anak dan remaja. Dengan demikian para mahasiswa yang mengambil mata kuliah ini di samping membuat karya tari yang murni (karya sendiri) juga harus mengajarkankan kepada penarinya.

Dari hasil pengamatan para mahasiswa yang kurang berhasil di dalam membuat karya tari itu terutama adalah dari segi gerak tarinya dan pemilihan peraga tari. Ada beberapa unsur untuk keberhasilan membuat karya seni tari anak. Antara lain adalah : gerak, kostum tari, iringan, tata rias, dan penari.

Unsur gerak memegang peranan yang amat penting di dalam pembuatan karya tari. Maka unsur inilah yang akan peneliti kaji lebih jauh untuk menunjang 
keberhasilan mahasiswa dalam membuat karya tari anak. Adapun pendekatan yang dipergunakan di dalam memecahkan masalah ini adalah dengan metode individual.

Gerak tari yang dipergunakan bukan gerak wantah atau gerak sehari-hari, tetapi gerak yang sudah mengalami stilisasi, penghalusan dan distorsi. Untuk membuat gerak tari anak perlu membutuhkan seleksi yang lebih rumit. Karena gerak tari untuk anak berbeda dengan gerak tari untuk orang dewasa. Membuat gerak tari anak lebih spesifik dan harus di sesuaikan dengan daya nalar, imajinasi dan dunia anak-anak.

Gerak tari yang dipergunakan di dalam membuat karya tari anak, pada umumnya adalah geraknya sederhana, mudah diikuti oleh anak, banyak menggunakan pengulangan, serta menggambarkan kehidupan dunia anak-anak Pola lantai juga sederhana, tema yang dipilih biasanya difokuskan pada kehidupan mereka, seperti bermain, tentang dunia binatang, tentang alam, atau pekerjaan manusia sehari-hari.

Secara umum ada 4 tahap yang harus dilalui mahasiswa untuk membuat karya tari, yaitu eksplorasi, improvisasi, evaluasi dan forming. Eksplorasi adalah mengamati alam, tanaman, binatang atau apapun yang akan dijadikan objek tari secara langsung. Improvisasi adalah bergerak bebas, yaitu dari hasil eksplorasi kemudian dituangkan ke dalam gerak secara bebas. Evaluasi adalah menyeleksi dari hasil improvisasi untuk dipilih gerak-gerak yang bisa dijadikan gerak tari sesuai dengan objeknya. Forming adalah bentuk akhir, yaitu gerak yang telah di dapat dari evaluasi untuk dijadikan gerak tari. Keempat tahap tersebut harus dapat dilalui mahasiswa dengan baik, jika ada salah satu dari keempat tahapan tersebu kurang, maka hasil yang akan di dapat juga kurang memuaskan.

Tujuan penelitian ini adalah untuk peningkatkan kualitas garap tari anak pada mahasiswa jurusan seni tari semester genap tahun 2005/2006.

Adapun manfaat yang di dapat dari penelitian ini adalah cukup besar, yaitu:

Bagi mahasiswa dengan hasil penelitian ini nantinya para mahasiswa menjadi terbiasa menggarap karya tari anak dan sudah tidak mengalami hambatan lagi.

Bagi dosen, jika telah ditemukan hambatan yang dialami mahasiswa, serta metode yang cocok untuk mengatasinya maka dosen tinggal mengarahkan dan akan dijadikan pengalaman pada semester berikutnya.

Bagi program studi, dengan karya tari yang dihasilkan oleh mahasiswa baik, maka akan mengangkat nama program studi khususnya dan UNY pada umumnya sekaligus koreografi anak benar-benar dapat dijadikan sebagai unggulan.

\section{B. Kajian Teori}

Membuat garapan tari bagi mahasiswa program studi seni tari adalah suatu keharusan. Untuk dapat membuat karya tari yang baik dan berkualitas memerlukan banyak latihan dan banyak pengalaman. Ada beberapa buku yang dapat dipergunakan sebagai acuan untuk berkarya tari. Antara lain adalah buku yang berjudul Koreografi yang ditulis oleh Sal Murgiyanto. (1983 : 6-8) Di dalam buku itu disebutkan bahwa untuk menjadi penata tari yang baik harus mempunyai kemampuan sebagai berikut :

\section{a. Ketrampilan gerak}

Banyak yang percaya bahwa penguasaan ketrampilan gerak dalam tari jawa di sebut wiraga yang di topang oleh wajah yang menawan merupakan satusatunya syarat seorang penari untuk mencapai kesuksesan. Akan tetapi, jika salah menggunakannya dapat merugikan penari sendiri.

\section{b. Penghayatan dan kemampuan dramatik}

Dalam menari seorang penari dituntut untuk bergerak dengan penuh perasaan. Unsur ini disebut wirasa dalam tari jawa, maksudnya seorang penari harus benar-benar menghayati gerak yang dilakukannya sesuai dengan tuntutan ideal tarinya. Rangkaian gerak tari yang baik yang dibawakan tidak dengan keterlibatan emosi dan jiwa penarinya akan kelihatan kosong tidak berjiwa. Jika seorang penari menarikan seorang tokoh dalam sebuah drama tari misalnya, maka kemampuan menjiwai peran itu atau kemampuan dramatik menjadi sangat penting. Kemampuan semacam ini sangat dituntut dalam bentuk penyajian seperti Wayang wong, Arja, Topeng dan bentuk-bentuk dramatari yang lain.

\section{c. Rasa irama}

Rasa irama atau kemampuan membedakan frase-frase yang menjadi bagian pokok dari musik merupakan kemampuan yang harus dimiliki oleh seorang penari. Seorang penari harus mampu bergerak baik seirama dengan ketukan maupun di sela-sela ketukan. Dalam tari tradisi, tidak masuk akal rasanya jika ada seorang penari yang tidak dapat mengenali irama pukulan gendang pengiring tarian. Di samping mengenal irama musik pengiring, seorang penari harus mampu pula melakukan irama gerak tari, yang meliputi : pengaturan cepat lambat, berat ringan serta peletakan aksen-aksen gerak sesuai dengan kebutuhan tarian.

\section{d. Rasa ruang}

Rasa ruang atau rasa pentas adalah kemampuan yang membuat seorang penari secara spontan mampu menempatkan diri sehingga tercapai keseimbangan pentas. Termasuk di dalamnya kemampuan untuk memahami apa yang dirasakan oleh penonton dan kemampuan menampilkan berbagai masalah kecil yang membuat pertunjukan menjadi lebih baik. Kemampuan ini jika 
secara gegabah digunakan dapat membunuh keidealan pertunjukan. Seorang penari yang selalu mencari tempat terang atau selalu menuntut perhatian penonton tanpa memperdulikan suasana pentas dan peranannya, jelas bukan seorang penari yang baik.

e. Daya ingat

Daya ingat yang jelek dalam tarian kelompok sangat merugikan. Kemampuan ini sangat berharga dalam kelompok tari profesional sebab seorang penari yang pelupa bisa mengakibatkan seluruh komposisi berantakan, apalagi dalam sebuah tarian tunggal. Seorang penari yang lupa dapat kehilangan konsentrasinya, sehingga seluruh komposisi kehilangan kontak dengan penonton. Akan tetapi jika dimulai sejak awal daya ingat ini dapat dilatih.

f. Kemampuan kreatif

Sekalipun dalam kadarnya yang besar, kemampuan ini memang lebih dimiliki oleh penata tari, tetapi seorang penari yang baik harus pula memiliki kemampuan kreatif. Kemampuan ini akan memudahkan bekerja sama dengan lebih dari seorang penata tari yang masing-masing memiliki pendekatan kreatifnya yang khas. Meskipun dengan kadar yang tidak sama tingginya, baik penari maupun penata tari harus memiliki kemampuan-kemampuan di atas. Kekurangan di salah satu bidang dapat saja diimbangi dengan kelebihan di bidang yang lain. Berbeda dengan seorang penari, seorang penata tari adalah seorang yang merencana, mengatur dan bertanggung jawab atas sebuah karya tari. Tugasnya meliputi pekerjaan mendesain, merencana, dan membangun ditambah dengan merencakan agar karyanya dapat dikomunikasikan kepada penonton lewat penafsiran penari-penarinya. Penata tarilah yang memutuskan bagaimana elemen-elemen produksi harus diorganisir. Untuk itu, ia dapat menunjuk pembantu-pembantunya. Namun, keputusan terakhir tentang bagaimana tarian itu harus disajikan bergantung kepadanya.

Di samping itu seorang penata tari harus :

a. Memiliki sikap yang terbuka, selalu bersedia dengan teliti mengamati tingkah laku sesamanya, baik secara emosional maupun secara jasmani.

b. Memahami keunikan dari setiap pribadi, mulai dari pribadinya sendiri yang benar-benar harus ia kenal, dan pribadi orang lain yang memiliki keunikan masing-masing.

c. Mempunyai rasa struktural, mampu menangkap dan menghayati segala bentuk dan wujid yang hadir di sekitarnya.

d. Memiliki rasa dramatik, peka terhadap perkembangan situasi dramatik baik yang ditulis di dalam skenario yang nyata maupun dalam bentuknya yang lebih abstrak.

e. Memiliki kemampuan mematut, kemampuan untuk membuang gerakan yang vulgar dari gerakan yang halus, kemampuan untuk tidak mencampur aduk gerakan yang lemah gemulai dengan gerakan primitif

f. Memiliki sifat-sifat cerdik, cekatan dan cakap menilai.

g. Memiliki kemampuan bahasa. Seorang penata tari dengan pikiran yang tajam dan penguasaan bahasa yang jelas atau puitis akan mudah menyampaikan maksudnya kepada para penarinya. Kemampuan ini akan sangat berguna untuk tari-tarian yang bernilai sastra.

h. Benar-benar menguasai masalah yang hendak diungkapkannya.

Sementara itu Sumandiyo Hadi dalam bukunya Aspek-aspek dasar Koreografi Kelompok (1996 : 36-54), mengatakan bahwa proses dalam membuat koreografi memerlukan beberapa tahap. Yaitu :

a. Eksplorasi : proses penjajagan, sebagai pengalaman untuk menanggapi objek dari luar, atau aktivitasnya mendapat rangsang dari luar. Ada 2 macam eksplorasi, yaitu eksplorasi bebas dan terstruktur. Eksplorasi bebas adalah eksplorasi yang tanpa direncanakan terlebih dahulu, jadi mahasiswa diberi kebebasan untuk mengeksplorasi seseuatu yang sesuai dengan keinginannya. Sedangkan eksplorasi terstruktur adalah eksplorasi yang sudah direncanakan terlebih dahulu. Untuk penelitian kali ini eksplorasi yang dipergunakan adalah eksplorasi terstruktur. Mahasiswa sudah diberi bekal untuk bereksplorasi dan sudah tahu yang ingin di eksplor. Untuk eksplorasi mahasiswa semester genap 2005/2006 tempat eksplorasi adalah Kebun binatang Gembira Loka. Dengan alasan, banyak mahasiswa yang menggarap karya tari dengan tema dunia binatang.

b. Improvisasi : menuangkan ide dari hasil eksplorasi. Setelah selesai bereksplorasi para mahasiswa kemudian menuangkan hasilnya ke dalam bentuk gerak disesuaikan dengan tema yang telah di tentukan

c. Pembentukan : hasil dari improvisasi diidentifikasi dan diseleksi gerak-gerak yang tidak sesuai dengan tema dibuang atau diperhalus yang sudah sesuai bisa dipergunakan (Evaluasi). Untuk dapat menjadi suatu bentuk tarian yang sesuai dengan ide yang diinginkan masih diperlukan juga kemampuan dari penata tari untuk meletakkan gerak-gerak yang sama dan sesuai sehingga menjadi gerak yang runtut dan enak untuk dilihat.

Koreografi anak adalah pembuatan gerak tari anak yang juga harus melalui proses seperti tersebut di atas. Penata tari yang sekaligus juga mahasiswa sebelum menata sebuah karya tari, diharapkan telah memahami pengetahuan yang seharusnya dimiliki oleh seorang penata tari. Oleh sebab itu mata kuliah ini adalah kelanjutan dari mata kuliah sebelumnya yang telah ditempuh oleh mahasiswa, yakni Mata Kuliah Komposisi dan Koreografi I. Mata kuliah Komposisi dan Koreografi II ini adalah bentuk praktik dari Komposisi dan Koreografi I. Dengan demikian karena mata kuliah ini adalah awal dari latihan menggarap sebuah karya tari, tentu masih banyak kekurangan dan banyak kendalanya. Ada beberapa 
kendala yang umumnya dihadapi oleh para mahasiswa di dalam membuat gerak tari ini, terutama adalah di dalam membuat gerak tari yang sesuai dengan tema tari anak.

\section{Metode Penelitian}

1. Lokasi dan Waktu Penelitian

Lokasi untuk penelitian ini adalah di Jurusan Pendidikan Seni Tari Fakultas Bahasa dan Seni Universitas Negeri Yogyakarta. Waktu penelitian adalah bulan Februari 2006 s/d Mei 2006.

2. Subjek Penelitian

Sebagai subjek penelitian adalah mahasiswa yang mengambil mata kuliah Komposisi dan Koreografi II semester genap 2005/2006 sebanyak 22 mahasiswa.

3. Prosedur Penelitian

Cara pengumpulan dan analisis data dalam penelitian ini mempergunakan tindakan kelas dengan beberapa tahap. Menurut Wiriaatmadja (2006 : 252) tahapan-tahapan tersebut disebut dengan siklus yang setiap tahapnya merupakan rangkaian kegiatan perencanaan, kegiatan tindakan, kegiatan observasi dari penampilan, analisis dan refleksi.

Tahap pertama : peneliti mengidentifikasi garapan tari anak seluruh mahasiswa yang mengambil mata kuliah komposisi dan koreografi II semester genap 2005/2006, sebanyak 22 garapan. Mulai dari tahap awal yaitu eksplorasi. Pada tahap awal ini, mahasiswa tidak banyak mengalami hambatan. Kemudian meningkat pada tahap berikutnya, yaitu Improvisasi. Pada tahap ini ada beberapa mahasiswa yang mengalami hambatan, namun hambatan itu segera bisa di atasi. Hambatan pada tahap evaluasi terutama adalah masalah pemilihan gerak yang akan di pergunakan serta kostum. Karena garapan tari ini adalah hasil dari mahasiswa sendiri, maka mereka juga merencana sendiri masalah rias dan kostumnya disesuaikan dengan tema. Tahap berikutnya adalah tahap pembentukan. Hasil dari evaluasi sudah selesai dan sudah runtut. Garapan tari dari mahasiswa sudah jadi dan sudah bisa dilihat atau dipentaskan.

Dari 22 karya tari tersebut semuanya ditampilkan dan diamati wiraga, wirama, wirasa, kreativitas serta harmoninya. Hasil dari amatan tersebut disampaikan kepada para mahasiswa dan dikaji lagi kelemahan dan kekurangannya, guna melakukan perencanaan tindakan, pelaksanaan tindakan, dan observasi serta analisis dan refleksi yang berulang-ulang.

Tahap kedua : dari hasil tahap pertama peneliti kemudian memberikan tindakan kelas secara individual. Dari masing-masing garapan peneliti memberikan treatmen atau perlakuan tindakan yang berbeda disebabkan garapan dari masingmasing mahasiswa juga berbeda. Setelah diberikan tindakan tersebut, ditampilkan lagi dan dikaji lagi kelemahan dan kekurangannya, guna melakukan perencanaan tindakan, pelaksanaan tindakan, dan observasi serta analisis dan refleksi pada tahap berikutnya.

Tahap ketiga : dari hasil tahap kedua ternyata masih ada 4 orang mahasiswa yang mengalami kesulitan di dalam membuat gerak tari yang sesuai dengan tema yang sudah di tentukan. Keempat mahasiswa itu masing-masing membuat karya tari dengan judul : Krucilan, Ceria Nelayan, Badendang dan Merak. Dari hasil temuan ini kemudian ditindaklanjuti dengan pemberian tindakan secara individual. Pemberian tindakan untuk masing-masing garapan juga berbeda. Krucilan kelemahannya pada kostum yang kurang sesuai. Ceria Nelayan kelemahannya pada gerak yang kurang dinamis sehingga akan membosankan jika dilihat oleh penonton dan terasa lama. Badendang kelemahannya pada iringan tari yang kurang menyatu dengan tarinya, dan tari Merak kelemahannya pada gerak yang kurang lincah serta kostum yang kurang sesuai. Dari masing-masing kelemahan garapan disampaikan kepada mahasiswa dan diberikan tindakan, pelaksanaan tindakan, dan observasi serta analisis dan refleksi dari tari yang belum sesuai dengan judulnya.

Demikian seterusnya berulang-ulang sehingga di dapatkan kualitas garap tari anak yang "ideal", yaitu tari yang sudah memenuhi syarat untuk dipentaskan dan tari yang sudah sesuai dengan temanya.

\section{Hasil Penelitian dan Pembahasan}

1. Hasil Penelitian

Penelitian ini mempergunakan subjek mahasiswa seni tari yang mengambil mata kuliah Komposisi dan Koreografi II pada semester genap 2005/2006. Di dalam mata kuliah ini mahasiswa diwajibkan untuk membuat koreografi (karya tari) anak sesuai dengan undian yang telah disepakai bersama. Bagi mahasiswa yang sebelumnya sudah pernah berkarya seni tari, hal ini tidak begitu menjadi masalah. Tetapi bagi mahasiswa yang belum pernah membuat karya tari ada masalah yang cukup membingungkan. Dari mahasiswa sebanyak 22 orang, (lihat tabel di bawah) setelah dilakukan penelitian dengan metode individual rata-rata mengalami kenaikan nilai yang cukup menggembirakan. Dalam melakukan penelitian ini mahasiswa tersebut di berikan tindakan kelas secara individual. Semua mahasiswa sebagai subjek penelitian, tahap demi tahap diamati perkembangan penggarapan geraknya di sesuaikan dengan tema yang diambil. Hasil dari pengamatan tersebut dicatat dan diinformasikan kepada masing-masing mahasiswa. Kemudian mahasiswa bersangkutan juga ditanyakan secara santai tentang kesulitan-kesulitan yang di hadapi dalam membuat karya tari. Dari hasil wawancara tersebut kemudian diberi tindakan untuk masing-masing karya tari dan diuji cobakan atau dianalisis. Disebabkan masing-masing karya tari berbeda satu sama lain, maka untuk perlakuan tindakan masing-masing juga 
berbeda, yaitu secara individual. Jika belum di dapatkan gerak tari yang sesuai dengan temanya, maka siklus ini diulang lagi. Demikan seterusnya dilakukan secara berulang-ulang sehingga di dapatkan gerak tari yang sesuai dengan temanya.

Setelah mendapatkan tindakan kelas dengan metode individual, maka di dapatkan hasil penilaian dari mahasiswa yang diteliti menunjukkan adanya perbaikan atau peningkatan yang cukup menggembirakan. Dengan menyertakan tiga orang pengamat dari luar (bukan dosen pengampu mata kuliah) yang menilai hasil dari karya tari anak tersebut di dapat nilai rata-rata :

\begin{tabular}{|l|l|c|c|}
\hline No & \multicolumn{1}{|c|}{ Judul Karya Tari } & Nilai awal & Nilai akhir \\
\hline 1. & Turonggo Hamanrang Mega & 75 & 80 \\
2. & Tetanen & 70 & 78 \\
3. & Sumpringan & 72 & 78 \\
4. & Krucilan & 60 & 75 \\
5. & Perang-Perangan & 75 & 82 \\
6. & Yoga Tamtama & 75 & 85 \\
7. & Sunda Manda & 72 & 80 \\
8. & Angsa & 73 & 80 \\
9. & Meong & 73 & 80 \\
10. & Ngemban Lare & 74 & 80 \\
11. & Kupu Ayu & 75 & 85 \\
12. & Baris Gloco & 72 & 80 \\
13. & Canthing Ayu & 76 & 78 \\
14. & Kijang Kasmaran & 70 & 90 \\
15. & Mojang Riang & 60 & 78 \\
16. & Ceria Nelayan & 68 & 72 \\
17. & Tenun & 68 & 77 \\
18. & Malenggang & 70 & 77 \\
19. & Ginjar & 72 & 78 \\
20. & Kenes & 62 & 80 \\
21. & Badendang & 64 & 75 \\
22. & Merak & & 75 \\
\hline
\end{tabular}

Sebagai alat ukur untuk menilai keberhasialan karya tari ini adalah Wiraga, Wirama, Wirasa, Kreativitas serta Harmoni. Wiraga adalah cara melakukan gerak tari/ teknik tari. Wirama adalah kesesuaian antara gerak tari dengan irama musik yang mengiringi. Wirasa adalah cara/ teknik merasakan (menghayati) gerak di sesuaikan dengan irama. Kreativitas adalah pengembangan ide gerak tari yang ditampilkan di sesuaikan dengan temanya. Harmoni adalah keselarasan atau kesesuaian antara keempat unsur tersebut di atas. Nilai awal (pre test) adalah hasil yang di dapatkan sebelum mahasiswa dikenai penelitian tindakan. Nilai akhir (post tes) adalah hasil yang di dapatkan setelah mahasiswa dikenai tindakan penelitian dengan diamati oleh pengamat pada waktu mengamati nilai awal (pre tes) ditambah dengan tiga orang pengamat dari luar yang bukan penilai awal.

Dari hasil nilai akhir yang di dapatkan ternyata dari masing-masing. pengamat memberikan nilai yang hampir sama untuk masing-masing karya tari. Setelah di rata-rata hasil akhir nilai yang didapat dari masing-masing pengamat di dapatkan nilai akhir (post tes) seperti yang ada pada tabel di atas. Dari 22 mahasiswa yang dijadikan subjek penelitian nilai yang di dapat memang cukup bervariasi. Ada nilai yang mengalami lonjakan cukup tinggi, tetapi ada pula yang hanya mengalami kenaikan sedikit. Dari sejumlah mahasiswa yang dijadikan subjek penelitian ada 4 orang mahasiswa yang mendapatkan nilai akhir tinggi mereka masing-masing adalah garapan tari dengan judul : Perang-Perangan, Yoga Tamtama, Kupu Ayu, dan Kijang Kasmaran. Dari keempat garapan tari mahasiswa yang mendapatkan nilai tinggi ini, diunggulkan untuk dijadikan bahan Workshop tari bagi guru-guru se Kabupaten Sleman. Ke depan, bahan ini nantinya juga akan dijadikan materi untuk lomba tari tingkat kabupaten/ Provinsi.

\section{Pembahasan}

Sementara itu, ada empat garapan tari yang pada nilai awal masih medapatkan nilai yang kurang baik tetapi pada nilai akhir sudah mendapatkan hasil nilai yang cukup menggembirakan. Keempat karya tari tersebuat adalah : Krucilan, Ceria Nelayan, Badendang, dan Merak. Krucilan yang pada nilai awal hanya mendapatkan nilai 60 tetapi pada nilai akhir sudah mampu mendapatkan nilai 75 . Ceria Nelayan nilai awal mendapat nilai 60 , nilai akhir 72 . Badendang nilai awal 62, nilai akhir 75. Merak nilai awal 64 pada nilai akhir 75 .

Dari 22 garapan tari anak, ada 7 garapan yang diperuntukkan bagi anak usia Sekolah Dasar (SD), 8 garapan untuk anak usia Sekolah Menengah Pertama (SMP), dan 7 garapan yang diperuntukkan bagi anak usia Sekolah Menengah Atas (SMA). Secara lengkap data dari masing-masing garapan dengan judul garapannya adalah sebagai berikut 


\begin{tabular}{|l|l|c|}
\hline No & \multicolumn{1}{|c|}{ Judul Karya Tari } & Materi untuk \\
\hline 1. & Turonggo Hamanrang Mega & SMP \\
2. & Tetanen & SMP \\
3. & Sumpringan & SD \\
4. & Krucilan & SD \\
5. & Perang-Perangan & SD \\
6. & Yoga Tamtama & SD \\
7. & Sunda Manda & SD \\
8. & Angsa & SD \\
9. & Meong & SD \\
10. & Ngemban Lare & SMP \\
11. & Kupu Ayu & SMP \\
12. & Baris Gloco & SMP \\
13. & Canthing Ayu & SMP \\
14. & Kijang Kasmaran & SMP \\
15. & Mojang Riang & SMP \\
16. & Ceria Nelayan & SMA \\
17. & Tenun & SMA \\
18. & Malenggang & SMA \\
19. & Ginjar & SMA \\
20. & Kenes & SMA \\
21. & Badendang & SMA \\
22. & Merak & SMA \\
\hline
\end{tabular}

Penari dari masing-masing garapan tidak sama, untuk materi anak Sekolah Dasar yang menarikan juga harus anak usia Sekolah Dasar. Materi untuk Sekolah Menengah Pertama penarinya juga harus anak seusia Sekolah Menengah Pertama. Demikian halnya untuk materi Sekolah Menengah Atas, penarinya juga harus anak usia Sekolah Menengah Atas.

Banyak kendala yang dihadapi oleh koreografer atau penata tari anak yang sekaligus adalah mahasiswa yang mengambil mata kuliah Komposisi dan Koreografi II. Kendala-kendala tersebut antara lain adalah : peraga tari atau penari, jadwal latihan, jarak rumah antara penari dan penata tari, kesesuaian iringan dan sebagainya. Peraga tari atau penari adalah anak-anak usia SD sampai SMA, oleh sebab itu kendala seperti pemilihan peraga tari, pengaturan jadwal untuk bisa latihan di luar jam-jam kesibukan anak sekolah, jarak rumah antara penata tari

dengan penari dan sebagainya selalu muncul di mata kuliah ini. Penelitian kali ini belum meneliti tentang kendala-kendala tersebut, tetapi masih terbatas hanya pada upaya peningkatan kualitas garap koreografi anak, diharapkan di tahun mendatang ada yang meneliti lebih jauh tentang kendala yang dialami oleh penata tari yang mempergunakan penari anak-anak usia Sekolah Dasar sampai Sekolah Menengah Atas. Masih banyak pula unsur lain yang mendukung keberhasilan sebuah pementasan atau karya seni tari, tetapi karena keterbatasan yang ada pada diri peneliti maka unsur-unsur yang lain tersebut belum dapat teramati.

\section{E. Penutup}

1. Simpulan

Dari hasil penelitian ini dapat disimpulkan bahwa, tindakan kelas dengan metode individual sesuai untuk mahasiswa yang mengambil mata kuliah koreografi atau membuat karya tari. Karena dengan metode individual mahasiswa akan mempunyai banyak waktu untuk mengutarakan kesulitan-kesulitannya di dalam membuat karya tari. Dengan metode individual mahasiswa juga akan tumbuh rasa percaya diri untuk bangkit dan mampu membuat karya tari.

Mata kuliah Komposisi dan Koreografi II ini adalah mata kuliah awal yang mewajibkan mahasiswa untuk berkarya (membuat) tari. Kemampuan awal dari masing-masing mahasiswa tidak sama. Dengan latar belakang yang demikian, maka di dalam berkarya taripun ada mahasiswa yang sudah mampu berkarya tari dengan lancar (baik), namun ada pula yang tersendat-sendat dan butuh bimbingan secara intensif.

2. Saran

Untuk penelitian yang akan datang barangkali bisa diamati atau diteliti lebih spesifik hal-hal yang mendukung keberhasilan sebuah karya tari, seperti : latar belakang mahasiswa, rias dan busana, iringan, tata cahaya, kualitas penari/pendukung, atau hambatan-hambatan lain yang dihadapi mahasiswa, dan sebagainya.

\section{Daftar Pustaka}

Arikunto, Suharsimi. 1989. Prosedur Penelitian Suatu Pendekatan Praktik. Jakarta : Bina Aksara

Arikunto dkk, 2006. Penelitian Tindakan Kelas. Jakarta : Bumi Aksara

Faisal, Sanapiah. 1995. Format-Format Penelitian Sosial Dasar-dasar dan Aplikasi. Jakarta : PT Raja Grafindo Persada

Kurikulum FBS 2002, 2006. (Revisi kedua) Universitas Negeri Yogyakarta

Kussudiardja, Bagong, 1992. Jejak dan Pengakuan Bagong Kussudiardja.

Yogyakarta : Padepokan Press 
Madya, Suwarsih, 2006. Teori dan Praktik Penelitian Tindakan Action Research. Bandung : Alfabeta

Marzuki. 1989. Metodologi Riset. Yogyakarta : BPFE-UII

Morris, Desmond. 1977.Manwatching : A Field Guide to Human Behavior. New York : Harry N. Abrams Inc

Murgiyanto, Sal. 1983. Koreografi Pengetahuan Dasar Komposisi Tari. Jakarta DEPDIKBUD

Smith, Jacqueline. 1985. Komposisi Tari Sebuah Petunjuk Praktis Bagi Guru. Terjemahan Ben Suharto. Yogyakarta : Ikalasti.

Soedarsono, RM. Metodologi Penelitian Seni Pertunjukan dan Seni Rupa. Cetakan kedua. Bandung : Masyarakat Seni Pertunjukan Indonesia, 2001. Sumandiyo Hadi, Y. 1996. Aspek-aspek Dasar Koreografi Kelompok. Yogyakarta: Manthili

Wardhana, Wisnoe 1990. Pendidikan Seni Tari Buku Guru Sekolah Menengah Pertama. Jakarta : Depdikbud

Wiriaatmadja, Rochiati, 2006. Metode Penelitian Tindakan Kelas untuk Meningkatkan Kinerja Guru dan Dosen.Bandung : PT. Remaja Rosdakarya 